\title{
LOAN EFFICIENCY IN THE VISEGRAD COUNTRIES*
}

\author{
Kristína KOČIŠOVÁ
}

Financial markets in the Visegrad countries have undergone several changes in lending business over the past decade. This study evaluates the efficiency of the largest commercial banks by focusing on their lending decisions using Data Envelopment Analysis. First, we define the concept of efficiency, then we analyse loan efficiency between 2007 and 2013. The results indicate that average efficiency declined. When we studied the loan efficiency in each country separately, we found that Hungarian banks had the lowest efficiency while the highest efficiency was achieved mainly by Czech banks. The results of the study also suggest that efficiency is positively related to profitability and capital adequacy, and negatively related to the share of non-performing loans, which confirms the bad management hypothesis.

Keywords: loan efficiency, commercial banks, V4 countries, Data Envelopment Analysis

JEL classification indices: $\mathrm{C} 14, \mathrm{G} 21$

\section{INTRODUCTION}

Over the past decade, financial markets in the Visegrad countries (V4) have undergone several changes that have significantly affected the performance of their banks. One of the consequences of the global financial crisis was the growth of non-performing loans (NPL) and the growth of their share on total gross loans. For example, the average share of NPL in banks, covered by this paper, rose from 5 to $10 \%$ between 2007 and 2013. The subject of NPLs has attracted more attention in recent years. Several studies examined bank failures and found that assets

* This work was supported by the Slovak Scientific Grant Agency as part of the research project VEGA 1/0446/15.

Kristína Kočišová, Associate Professor at Faculty of Economics, Department of Banking and Investment, Technical University of Košice, Slovak Republic.

E-mail: kristina.kocisova@tuke.sk 
quality was an indicator of insolvency (Demirgüç-Kunt 1989; Barr - Siems 1994) since banks had a high level of NPLs before bankruptcy. These authors found that when the volume of bad loans increased, the banks' ability to increase their performance declined.

Besides NPLs, one important aspect in the measurement of bank performance is efficiency. This affects the stability of the banking industry and thus the efficiency of the entire financial system. Banking sectors are still the primary form of financial intermediation in the $\mathrm{V} 4^{1}$ countries, being the major channel for the mobilisation of domestic savings and their transformation into a major source of external capital to firms. Banks are key players in the payment systems; therefore, the development of the banking sector's efficiency is crucial for the growth of economies in the V4 countries.

According to Resti (1996), at the macroeconomic level, bank efficiency represents a socially optimal objective. It reduces the costs of financial intermediation, the transfer of funds from savers to producers. Consequently, central banks are seriously interested in the accomplishment of operating practices and market equilibrium that grant the maximum productive efficiency, provided that this does not result in a monopoly, which would expropriate consumers from the advantages due to the reduction in average costs. Of course, given some crisis situations, it may be optimal to postpone the search for efficiency, concentrating on the defence of the system stability and preventing dangerous "domino effects" that can arise, when the less productive institutions are forced to quit the market in a traumatic way. Nevertheless, the illusory dilemma between efficiency and stability exists only in the short term: when things are put in a wider perspective, efficiency appears as the only endogenous force, which can ensure solidity of a banking system. Our question is how NPLs affect the efficiency of commercial banks.

A number of researchers have found that failing banks tend to be located far from the best practice frontier, which means that they reach lower efficiency (Berger - Humphrey 1992; Barr - Siems 1994; DeYoung - Whalen 1994; Wheelock - Wilson 1995). Other studies also indicate that there is a negative relationship between efficiency and problem loans even among banks that do not fail (Hughes - Moon 1995; Resti 1996; Kwan - Eisenbeis 1996).

The purpose of the present study is to define the concept of efficiency and analyse the loan efficiency of commercial banks in the V4 countries between 2007 and 2013. We shall determine factors (bank-specific variables such as structure of assets and liabilities, earning structure, liquidity ratio, capital adequacy ratio,

1 Czech Republic, Hungary, Poland, and the Slovak Republic. 
etc.) positively and negatively related to loan efficiency. In addition to those objectives, this paper deals with the following research questions:

1. Is the banking sector of the $\mathrm{V} 4$ countries performing efficiently?

2. Has the loan efficiency of commercial banks in the V4 countries changed over the past few years?

3. What are the main sources of inefficiency, and is there a way to improve the loan efficiency of commercial banks in the V4 countries?

4. How do major structural characteristics of banks affect the efficiency of banks' lending behaviour?

Answers to these questions may be beneficial to three main groups. Knowledge of the level of efficiency is important to bank managers since it reflects the quality of daily operations in utilising inputs and outputs, and other decisions can be based on that knowledge. Policymakers are another group that may benefit from that information, because they can use it to compare the banking sector's performance before and after any regulatory changes took place and, consequently, they can evaluate whether the changes were beneficial to the banking sector. Finally, researchers can also benefit from a paper analysing efficiency of the banking sector. They can use previous studies in that area to observe the gradual development in efficiency measuring techniques, which may enable them to identify gaps in their research.

This study is divided into four sections. Section 1 is a review of publications dealing with efficiency assessment in banking, in particular using the Data Envelopment Analysis (DEA) to evaluate efficiency on the credit market. Section 2 explains the methods used for efficiency measurement. Section 3 describes the selection of variables as well as gives an analysis of collected data, and the presentation of findings. The last section provides a summary of key findings.

\section{LITERATURE REVIEW}

The earliest techniques, which used to measure efficiency through ratio analysis, examined financial statements of individual banks and compared them with a benchmark. Probably the best known ratios used to measure performance of commercial banks are ratios of profitability, e.g. return on assets (RoA) and return on equity (RoE). To evaluate loan efficiency, the best known is the ratio of NPLs as a share of non-performing loans on total gross loans. ${ }^{2}$

2 Resti (1996); Tabak et al. (2011); Funso et al. (2012). 
More recent methods are labelled as parametric methods and non-parametric methods, methods of multi-criteria decision and the Balanced Scorecard method. ${ }^{3}$ Parametric methods include the Stochastic Frontier Approach (SFA), the Thick Frontier Approach (TFA), and the Distribution Free Approach (DFA). ${ }^{4}$ Non-parametric methods include the Data Envelopment Analysis (DEA) and the Free Disposal Hull (FDH). ${ }^{5}$ Multi-criteria decision problems are described by a set of alternatives, a set of evaluation criteria, and by links between the criteria and alternatives. A decision maker enters basic information about criteria and alternatives to formulate a multi-criteria model. This model has the option to enter additional information the investigator may have failed to state explicitly, which would not have been included in the basic model. ${ }^{6}$ Table 1 presents a more detailed overview of the relevant literature. Each author used different input and output variables to study the banking sector in the evaluated country according to the method he/she selected.

As can be seen in Table 1, there are few studies only which use the NPLs value as an input directly in efficiency measurement, ${ }^{7}$ and the same can be said about studies which measure efficiency of the money lending business of commercial banks. ${ }^{8}$ These authors evaluated loan efficiency or efficiency of the credit market in the national economy (Sweden and Turkey). The aim of our study is to expand the use of the DEA technique to assess the relative loan efficiency of the largest commercial banks in the V4 countries using the bad loans value as the input variable of the model.

\section{METHODOLOGY}

Data Envelopment Analysis (DEA) was developed by Charnes et al. (1978). Sherman - Gorld (1985) was the first to apply DEA to banking. The DEA calculates the relative efficiency scores of various Decision-Making Units (DMUs) in a particular sample. The DMUs could be banking sectors, banks, or branches of banks. The DEA compares each banking sector/bank/branch in the sample with the best practice in the sample, whereby it distinguishes between the efficient

3 Gavurová (2011, 2012); Šoltés - Gavurová (2013).

4 Rossi et al. (2005); Karim et al. (2010), who used them to measure efficiency in the European and Malaysian banking sectors.

$5 \quad$ Hartman - Storbeck (1996); Resti (1996); Zago - Dongili (2006); Dai (2010); Cinar (2011); Tabak et al. (2011).

$6 \quad$ Kosmidou et al. (2006); Shaverdi et al. (2011); Akkoc - Vatansever (2013).

7 Hartman - Storbeck (1996); Zago - Dongili (2006); Dai (2010); Cinar (2011).

8 Hartman - Storbeck (1996); Cinar (2011). 
Table 1. Detailed literature review, 1996-2013

\begin{tabular}{|c|c|c|c|}
\hline $\begin{array}{l}\text { Author } \\
\text { (Year) }\end{array}$ & $\begin{array}{l}\text { Research } \\
\text { sample }\end{array}$ & Research methodology & Results \\
\hline $\begin{array}{l}\text { Hartman } \\
\text { - Storbeck } \\
\text { (1996) }\end{array}$ & $\begin{array}{l}\text { Swedish com- } \\
\text { mercial banks } \\
\text { between } \\
1983 \text { and } 1992\end{array}$ & $\begin{array}{l}\text { DEA model: input variables } \\
\text { (interest cost, non-performing } \\
\text { loans); output variable (inter- } \\
\text { est revenue) }\end{array}$ & $\begin{array}{l}\text { Inefficiency is increasing throughout } \\
\text { the banking sector, which can be at- } \\
\text { tributed predominantly to increasing } \\
\text { credit losses. Previously regulated } \\
\text { industries tend to be supervised by } \\
\text { some public agency, instated mainly } \\
\text { for consumer protection purposes. Ac- } \\
\text { cording to the authors, DEA can be a } \\
\text { powerful tool for the regulator when } \\
\text { investigating the efficiency develop- } \\
\text { ment of the entire industry as well as } \\
\text { that of individual companies. }\end{array}$ \\
\hline Resti (1996) & $\begin{array}{l}\text { Italian com- } \\
\text { mercial banks } \\
\text { between } \\
1988 \text { and } 1992\end{array}$ & $\begin{array}{l}\text { Econometric model, } \\
\text { DEA model }\end{array}$ & $\begin{array}{l}\text { Econometric and linear programming } \\
\text { results do not differ dramatically when } \\
\text { based on the same data and conceptual } \\
\text { framework. The results of the study of } \\
270 \text { Italian commercial banks show } \\
\text { that there is a direct relationship be- } \\
\text { tween efficiency and assets quality. }\end{array}$ \\
\hline $\begin{array}{l}\text { Rossi et al. } \\
(2005)\end{array}$ & $\begin{array}{l}\text { Commercial } \\
\text { banks in Central } \\
\text { and Eastern } \\
\text { European coun- } \\
\text { tries between } \\
1995 \text { and } 2002\end{array}$ & $\begin{array}{l}\text { SFA model 1: total costs (op- } \\
\text { erating expenses), outputs } \\
\text { (loans, deposits, other earn- } \\
\text { ing assets), input prices (staff } \\
\text { expenses per total assets, op- } \\
\text { erating expenses per fixed as- } \\
\text { sets, expenses on interest per } \\
\text { deposits) } \\
\text { SFA model 2: total profits } \\
\text { (operating profits minus loan } \\
\text { loss provisions), outputs and } \\
\text { input prices (as in model 1) }\end{array}$ & $\begin{array}{l}\text { The analysis indicates a generally low } \\
\text { level of cost efficiency and an even } \\
\text { lower level of profit efficiency. They } \\
\text { tested several hypotheses of mana- } \\
\text { gerial behaviour using the Granger } \\
\text { causality approach based on the inter- }- \text { - } \\
\text { temporal relation between bank effi- } \\
\text { ciency and, e.g., problem loans. The } \\
\text { results show a negative correlation } \\
\text { between problem loans and efficien- } \\
\text { cy. The results provide evidence for } \\
\text { the bad luck hypothesis, suggesting } \\
\text { that exogeneity of bad loans triggers } \\
\text { inefficiency. }\end{array}$ \\
\hline $\begin{array}{l}\text { Zago - } \\
\text { Dongili } \\
\text { (2006) }\end{array}$ & $\begin{array}{l}\text { Italian banks } \\
\text { between } \\
1993 \text { and } 2004\end{array}$ & $\begin{array}{l}\text { DEA model 1: input variables } \\
\text { (total deposits, non-interest in- } \\
\text { come, total loans, bad loans), } \\
\text { output variables (labour costs, } \\
\text { intangible assets) } \\
\text { DEA model 2: input variables } \\
\text { (core deposits, securities, total } \\
\text { loans, bad loans), output vari- } \\
\text { ables (labour costs, intangible } \\
\text { assets, non-core deposits, free } \\
\text { capital) }\end{array}$ & $\begin{array}{l}\text { Once bad loans are considered, the } \\
\text { efficiency of banks increases signifi- } \\
\text { cantly. In addition, omitting bad loans } \\
\text { may underestimate the performance } \\
\text { of better credit quality banks. These } \\
\text { results suggest that a significant as- } \\
\text { pect of banking production - credit } \\
\text { quality - needs to be considered when } \\
\text { evaluating banks' performance for } \\
\text { regulatory purposes. }\end{array}$ \\
\hline Dai (2010) & $\begin{array}{l}\text { Chinese com- } \\
\text { mercial banks in } \\
2008\end{array}$ & $\begin{array}{l}\text { DEA model: input variables } \\
\text { (deposit to loan ratio, loan to } \\
\text { total assets ratio, NPL ratio, } \\
\text { loan concentration, interest } \\
\text { rate of lending); output vari- } \\
\text { ables (ROA, loan yield) }\end{array}$ & $\begin{array}{l}\text { The differences in efficiency of the } \\
\text { banks' lending business are perceived } \\
\text { mainly in funds utilization. Differ- } \\
\text { ent commercial banks have different } \\
\text { scales of funds capitalization, but the } \\
\text { same service efficiency. }\end{array}$ \\
\hline
\end{tabular}


Table 1. continued

\begin{tabular}{|c|c|c|c|}
\hline $\begin{array}{l}\text { Author } \\
\text { (Year) }\end{array}$ & $\begin{array}{l}\text { Research } \\
\text { sample }\end{array}$ & Research methodology & Results \\
\hline $\begin{array}{l}\text { Karim et al. } \\
(2010)\end{array}$ & $\begin{array}{l}\text { Malaysian and } \\
\text { Singaporean } \\
\text { banks between } \\
1995 \text { and } 2000\end{array}$ & $\begin{array}{l}\text { SFA model: total costs (sum } \\
\text { of expenses for wages and } \\
\text { salaries, land, buildings, } \\
\text { equipment and interest on de- } \\
\text { posits), outputs (total loans, } \\
\text { total deposits, total invest- } \\
\text { ments), input prices (expenses } \\
\text { for wages and salaries paid to } \\
\text { employees, expenses for land, } \\
\text { buildings and equipment per } \\
\text { fixed assets, expenses on in- } \\
\text { terest per deposits) }\end{array}$ & $\begin{array}{l}\text { The objective of the paper was to } \\
\text { investigate the relationship between } \\
\text { NPLs and bank cost efficiency. The } \\
\text { results indicate that there is no sig- } \\
\text { nificant difference in cost efficiency } \\
\text { between banks in Singapore and Ma- } \\
\text { laysia, although banks in Singapore } \\
\text { exhibit a higher efficiency. The Tobit } \\
\text { simultaneous equation regression re- } \\
\text { sults clearly indicate that higher NPL } \\
\text { loan reduces efficiency. Likewise, } \\
\text { lower cost efficiency increases NPLs. }\end{array}$ \\
\hline Cinar (2011) & $\begin{array}{l}\text { Commercial } \\
\text { banks in Turkey } \\
\text { between } \\
2003 \text { and } 2009\end{array}$ & $\begin{array}{l}\text { DEA model 1: input variables } \\
\text { (interest expenses, non-per- } \\
\text { forming loans); output vari- } \\
\text { able (interest revenues) } \\
\text { DEA model 2: input vari- } \\
\text { ables (model 1 + non-interest } \\
\text { expenses), output variables } \\
\text { (model 1 + non-interest rev- } \\
\text { enues) } \\
\text { DEA model 3: input variables } \\
\text { (model 2), output variables } \\
\text { (model 2+ loans) }\end{array}$ & $\begin{array}{l}\text { Efficiency in the sector improved and } \\
\text { it was not dramatically affected by } \\
\text { the global crisis in } 2008 \text {. Large Turk- } \\
\text { ish banks improved their efficiency, } \\
\text { if we consider non-interest returns in } \\
\text { addition to interest gains. This con- } \\
\text { clusion implies that non-interest rev- } \\
\text { enues earned from diversified finan- } \\
\text { cial services have a crucial role in the } \\
\text { bank management. Results also show } \\
\text { that risk-taking behaviour was more } \\
\text { beneficial than conservative strategies } \\
\text { in the analysis period. }\end{array}$ \\
\hline $\begin{array}{l}\text { Tabak et al. } \\
\text { (2011) }\end{array}$ & $\begin{array}{l}\text { Brazilian banks } \\
\text { from June } 2000 \\
\text { to June } 2007\end{array}$ & $\begin{array}{l}\text { Measurement of loan efficien- } \\
\text { cy by ratio of non-performing } \\
\text { loans } \\
\text { DEA model: input variables } \\
\text { (deposits, operating expenses, } \\
\text { personnel expenses, interest } \\
\text { expenses), output variable } \\
\text { (loans) }\end{array}$ & $\begin{array}{l}\text { They used the Granger causality tests } \\
\text { to identify the inter-temporal relation- } \\
\text { ship between non-performing loans } \\
\text { and bank efficiency. They found that } \\
\text { inefficiency was the primary trigger } \\
\text { of soaring problem loans. Hence, it is } \\
\text { fundamental to study bank efficiency } \\
\text { since it precedes a macro-prudential } \\
\text { indicator: NPLs. Bank efficiency } \\
\text { measurement is important for the } \\
\text { banking system regulation and should } \\
\text { be used as an early indicator of finan- } \\
\text { cial stability. }\end{array}$ \\
\hline $\begin{array}{l}\text { Funso et al. } \\
\text { (2012) }\end{array}$ & $\begin{array}{l}\text { Commercial } \\
\text { banks in Nigeria } \\
\text { between } \\
2000 \text { and } 2010\end{array}$ & $\begin{array}{l}\text { Traditional measurement of } \\
\text { bank performance: Return on } \\
\text { Assets (ROA) }\end{array}$ & $\begin{array}{l}\text { They used a traditional profit theory to } \\
\text { formulate bank performance as a func- } \\
\text { tion of the ratio of NPLs, ratio of total } \\
\text { loans to total deposits and ratio of loan } \\
\text { loss provisions to classified loans. } \\
\text { A } 100 \% \text { increase in NPLs reduces } \\
\text { profitability (ROA) by about } 6.2 \% \text {, a } \\
100 \% \text { increase in loan loss provisions } \\
\text { also reduces the ROA by about } 0.65 \% \text {, } \\
\text { while a } 100 \% \text { increase in total loans } \\
\text { increases the ROA by } 9.6 \% \text {. }\end{array}$ \\
\hline
\end{tabular}


Table 1. continued

\begin{tabular}{l|l|l|l}
\hline $\begin{array}{l}\text { Author } \\
\text { (Year) }\end{array}$ & $\begin{array}{l}\text { Research } \\
\text { sample }\end{array}$ & Research methodology \\
\hline $\begin{array}{l}\text { Akkoc }- \\
\text { Vatansever }\end{array}$ & $\begin{array}{l}\text { Commercial } \\
\text { banks in Turkey } \\
\text { in 2010 }\end{array}$ & $\begin{array}{l}\text { Methods of multi-criteria } \\
\text { decision: AHP and TOPSIS }\end{array}$ & $\begin{array}{l}\text { They used methods of multi-criteria } \\
\text { decision to evaluate the performance } \\
\text { of commercial banks. The financial } \\
\text { performance of banks was evalu- } \\
\text { ated using 17 financial performance } \\
\text { indicators classified under 7 mean } \\
\text { categories (capital ratios, assets qual- } \\
\text { ity, liquidity, profitability, income } \\
\text { expenditure structure, activity ratios, } \\
\text { and branch ratios). }\end{array}$ \\
\hline
\end{tabular}

Source: Prepared by the author.

and inefficient DMUs. Thus, DEA is using the same multiple inputs to produce multiple outputs.

From the set of available data, DEA models identify the efficiency frontier, the efficiency score of each production unit and the recommendation for each inefficient production unit on how to modify their inputs and outputs to become efficient in a given set of production units and used criteria.

In this study, the units of analysis are the banks. Consider $n$ banks ( $D M U$, $j=1,2, \ldots, n)$, each consuming $m$ different inputs $\left(x_{i j}, i=1,2, \ldots, m\right)$ to produce $s$ different outputs $\left(y_{r r^{\prime}} r=1,2, \ldots, s\right)$. The matrix of inputs is marked as follows: $X=\left\{x_{i j}\right.$, $i=1,2, \ldots, m ; j=1,2, \ldots, n\}$, and the matrix of outputs is marked as follows: $Y=\left\{y_{r j}\right.$, $r=1,2, \ldots, s ; j=1,2, \ldots, n\}$. Since the used inputs and produced outputs have different levels of significance for each bank, they have different weights. The advantage of the DEA model is that the weights of the utilised inputs and produced outputs are the result of solving an optimization of a linear programming problem; they are not allocated on the basis of a subjective perception. The optimal weights are obtained by solving the following mathematical programming problem:

Max

$$
\sum^{s} u_{r} y_{r q} / \sum^{m} v_{i} x_{i q}
$$

Subject to

$$
v_{i} \geq 0 \quad i=1,2, \ldots, m
$$

where $u_{r}$ is the optimised weight of $r^{\text {th }}$ output $(r=1,2, \ldots, s), v_{i}$ is the optimized weight of $i^{\text {th }}$ input $(i=1,2, \ldots, m), y_{r q}$ are the produced amounts of $r^{\text {th }}$ output $(r=1,2, \ldots, s)$ for $D M U_{q}, x_{i q}$ are the consumed amounts of $i^{\text {th }}$ input $(i=1,2, \ldots, m)$ for $D M U_{q}, y_{r j}$ are the produced amounts of $r^{\text {th }}$ output $(r=1,2, \ldots, S)$ for $D M U_{j}(j=1,2, \ldots, n)$, and $x_{i j}$ are the consumed amounts of $i^{\text {th }}$ input $(i=1,2, \ldots, m)$ for $D M U_{j}(j=1,2, \ldots, n)$.

This functional linear program can be transformed into an ordinary linear program, which can be expressed as a dual problem. The obtained linear program- 
ming problem assumes a constant return to scale and it is known as the CCR (Charnes, Cooper and Rhodes) model. The assumption of a constant return to scale can be accepted only if the DMUs operate under the condition of their optimal size. Imperfect competition, financial constraints, control steps and other factors can cause DMUs not to operate at their optimal size. A DEA model that allows for calculations with a variable return to scale has been developed to overcome this problem. This model is called the BCC model (Banker, Charnes, Cooper). DEA models (CCR model or BCC model) can be based on inputs or outputs. The input-oriented models make recommendations of how inefficient units can achieve efficiency in the form of reductions on the inputs side. Outputoriented models require an increase on the outputs side to achieve efficiency. The efficiency of a particular $D M U_{q}$ can be obtained by solving the linear programming programs. Zijang (2006) defines input-oriented model with slack variables which assume a variable return to scale (BCC model) as follows:

Min

$$
\begin{gathered}
\theta_{q}-\varepsilon\left[\sum_{i=1}^{\mathrm{m}} \mathrm{s}_{\mathrm{i}}^{-} \mid \sum_{r=1}^{s} s_{r}^{+}\right] \\
\sum_{j=1}^{n} x_{i j} \lambda_{j}+s_{i}^{-}=\theta_{q} x_{i q} \\
\sum_{j=1}^{n} y_{r j} \lambda_{j}-s_{r}^{+}=y_{r q} \\
\sum_{j=1}^{n} \lambda_{j}=1 \\
\lambda_{j} ; s_{i}^{-} ; s_{r}^{+} \geq 0
\end{gathered}
$$

where $\theta_{q}$ is the efficiency of $\mathrm{DMU}_{\mathrm{q}}, \varepsilon$ is the non-Archimedean constant $\left(10^{-6}\right.$ or $\left.10^{-8}\right), s_{r}^{+}$and $s_{i}^{-}$are the input or output slacks, and $\lambda_{j}$ is the weight assigned to the $D M U_{j}(j=1,2, \ldots, n)$.

Performing a DEA analysis requires solving $n$ linear programming problems in the above form, one for each DMU. $D M U_{q}$ is termed fully efficient if and only if the optimal value $\theta_{q}=1$ and all the slack variables are equal to zero. If $\theta_{q}=1$ but the slack variables are not equal to zero, we can talk about "pseudo-efficiency". If the slack variables are equal to zero but $\theta_{q}<1$, then the value $\theta_{q}$ signals inefficiency. This inefficiency can be eliminated by a proportional (radial) reduction in all inputs of $D M U_{q}$ by $\left(1-\theta_{q}\right) 100 \%$ and thus a shift on the efficiency frontier can be achieved. If the slack variables are not equal to zero and $\theta_{q}<1$, it is necessary to perform non-radial shift expressed by slack variables to achieve efficiency. 
Efficiency calculated by the CCR model is often called overall efficiency. Overall efficiency of the $D M U_{q}$ can be decomposed into pure technical efficiency (calculated by a BCC model) and scale efficiency (SE). Decomposition of the overall technical efficiency is possible according to the following formula (Kočišová 2013):

$$
C C R_{q}=B C C_{q} \cdot S E_{q} .
$$

One component of the CCR efficiency is the scale efficiency (SE). If SE is equal to one, it means that the bank operates in conditions of a constant return to scale, so the bank operates at the most efficient scale. If SE is less than one, it means that the bank operates in conditions of a variable return to scale, so there is a scale inefficiency (SI) in the bank. The value of scale inefficiency can be calculated according to the following formula (Kočišová 2013):

$$
S I_{q}=1-S E_{q} \text {. }
$$

A number of different approaches can be used to model the banking process. Each of them is used to obtain a different aspect of efficiency measures. The most important are: production, operating and the intermediation approach. In this study, the operating approach is used.

The operating approach evaluates the bank's efficiency from the perspective of management of cost and revenues. On the side of inputs, there are usually all significant costs of basic banking activities, while the main sources of the bank's revenues are on the side of outputs. Interest expenses, personnel costs, capital costs, and fees and commissions paid are usually used as inputs and, e.g., interest revenues and received fees and commissions are considered to be outputs.

Under the production approach, banks are viewed as institutions making use of traditional production factors such as land, labour, and capital to produce different products and services to depositors and borrowers. Labour and operating costs for instance, are used as input and output variables, while the output variables are products and services such as loans and deposits.

According to Stavárek (2003), the intermediation approach seems to dominate empirical research in banking area. This approach assumes that the bank collects deposits and transfers them, using labour and capital, into loans. The intermediation approach describes banking activities as transforming the money borrowed from depositors into the money lent to borrowers. This transformation activity originates in the different characteristics of deposits and loans. Deposits are typically divisible, liquid, and riskless, whereas loans are indivisible, illiquid, and risky. In this approach, inputs include financial capital - the deposits collected and funds borrowed from financial markets, whereas the volume of loans and investment outstanding measures outputs. 
Authors of empirical publications have found that failing banks and banks with high level of problem loans tend to be far from the efficiency frontier. NPLs are one of the major causes of economic stagnation problems and can lead to efficiency problems of banks and the banking sector. According to Berger-DeYoung (1997), Williams (2004) and Rossi et al. (2005), we approach the matter in a direct way by linking managerial behaviour with the bank's efficiency. In this paper, we used regression analysis to examine how major structural characteristics of banks affect the efficiency of banks' lending behaviour. To examine this relation, we formulated the following regression model:

$$
E F F_{i}=\alpha_{0}+\sum_{j=1}^{n} \beta_{j} \cdot X_{j, i}
$$

where $E F F_{i}$ is the pure loan efficiency of $i$-the bank; and $X_{j, i}$ is the vector of explanatory variables, which represents major structural characteristics of $i$-the bank.

\section{EMPIRICAL ANALYSIS AND RESULTS}

We calculated the relative technical efficiency of the largest commercial banks in the V4 countries between 2007 and 2013. The analysis is based on the data of domestic banks representing more than $75 \%$ of total banking assets in their country. Naturally, the number of banks changed over the analysed period and the data of several banks from the V4 countries were not available for each year. Therefore, the sample contains the data of 54 banks only which operated on the domestic market throughout the analysed period. We analysed only commercial banks that were operating as independent legal entities. All saving banks (for example Prvá stavebná sporitel'na, a.s., Wustenrot stavebná sporitel'ňa, a.s., Slovak Republic), mortgage banks, and other specialised banks or credit unions were excluded from the estimation set. The data were extracted mainly from the Bankscope database (bankscope.bvdinfo.com/); the missing data were supplemented from the banks' annual reports. We used the banks' closing consolidated balance sheets and income statements prepared according to the international accounting standards. All data were reported in EUR as the reference currency. Figures in national currencies were converted by the official exchange rates of national central banks.

The term "relative" efficiency refers to the achieved efficiency within the group and given the criteria used (input and output variables according to the approach applied). In our analysis, we compared the relative efficiency of each bank and also the average efficiency of banks in the banking sector according to the bank headquarters to one of the four countries of the Visegrad group. 
For the evaluation of the relative efficiency, an operating approach that evaluates efficiency of costs and revenues management in the money lending business of commercial banks was used. We shaped the DEA model to measure the efficiency of banks' loan operations by choosing NPLs and interest expenses as inputs and interest revenues as outputs, as described by Hartman - Storbeck (1996) and Cinar (2011). These authors called this model "loan efficiency". The first input (NPL) was measured by the book value of impaired loans. The second input (interest expenses) was measured by the value of interest expenses on customer deposits. On the outputs side, there was only one variable (interest revenues), which represented the value of interest income on loans. When we focus on the income structure of commercial banks, we find that the proportion of income from commissions, fees, or revenue from financial derivatives transactions and securities trading in total profit is significantly less than that of loan interest income, which is why we used only one output variable in the form of interest revenues.

The model used in our analysis aims to measure the technical efficiency by focusing on the lending decisions of banks, i.e. it shows a relative performance measurement on the basis of loan productivity of banks. We used this model to evaluate the relative efficiency of a bank pertaining to given interest revenues, minimization of interest expenses, and bad loans. Cinar (2011) assumes that the attained interest revenues are a function of the amount the management of the bank has decided to lend as well as the price the bank has charged for its loans.

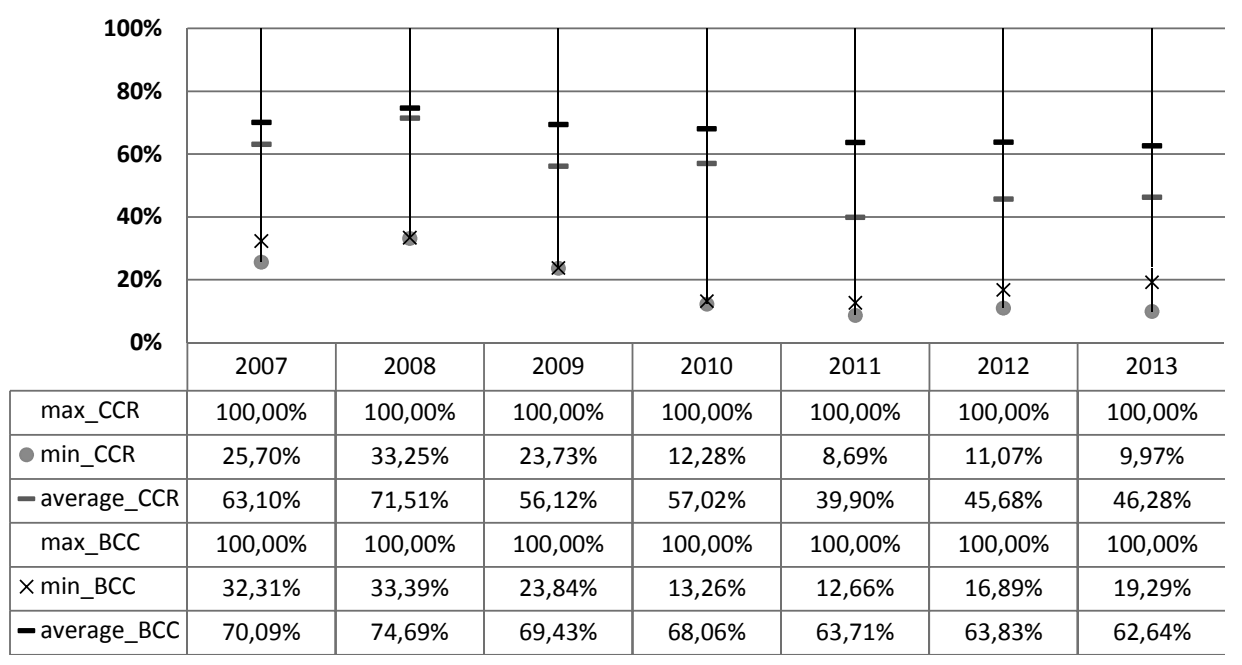

Figure 1. Average overall and pure loan efficiency

Source: Author's calculations. 
This approach has the advantage of obtaining larger differences between efficiency scores attained by the banks in the sample.

Following the described methodology, we calculated the efficiency of all banks in the estimation set. The overall loan efficiency (CCR model) and the pure loan efficiency (BCC model) were estimated using the EMS computer program provided by Scheel (2000). We pooled the cross-country data and used them to determine a common best practice efficiency frontier for each year.

Figure 1 shows the results of average CCR and BCC efficiencies obtained relative to the whole sample during the analysed period. Both models show that efficiency of the loan business has generally decreased over time. The table under Figure 1 presents the average result of the overall loan efficiency of all banks and their components. The mean of the overall loan efficiency at the beginning of the analysed period was $63.10 \%$, indicating that banks had to improve their efficiency by $36.90 \%$ on average. The average efficiency slightly rose to $71.51 \%$ in 2008, indicating decreasing room for efficiency improvement $(28.49 \%)$. Since 2008, the average overall loan efficiency decreased to reach its minimum in 2011. In that year, the average overall loan efficiency of all banks was $39.90 \%$ (room for efficiency improvement was at its peak, $60.10 \%$ ). In the past two years, the average overall loan efficiency increased slightly and stabilised at approximately $46 \%$. The average BCC efficiency was considerably higher than it was in the CCR model. We can observe the same trend in the pure loan efficiency. An improvement can be seen in the average pure loan efficiency between 2007 and 2008. The highest pure loan efficiency was reached in 2009 (74.69\%); since then, the average pure loan efficiency decreased, reaching its minimum at the end of the analysed period (2013: 62.64\%). The table shows that the highest efficiency was felt in 2008; that means that in 2008, banks were the most efficient in their management of costs and revenues. Since then, the average efficiency decreased, which may be attributed to the crisis that hit the banking sector in 2008 (this finding is in line with Cinar 2011). A greater variability was observed in overall loan efficiency. The overall loan efficiency fluctuated from $8.69 \%$ (2011) to $100 \%$, the pure loan efficiency fluctuated from $12.66 \%$ (2011) to $100 \%$, while variability was at its peak in 2011 and hit the bottom in 2008. Given our emphasis on credit quality, we also reported the trend of NPLs' growth in the analysed period. While the average loan efficiency has declined since 2008, the average value of the bad loans of the analysed banks increased from EUR 327,185 thousand in 2008 to the maximum of EUR 649,875 thousand in 2011, and since then it was kept at about the level of EUR 635,000 thousand.

To observe differences in average efficiency among the V4 countries, the level of efficiency was calculated separately for each country. The results are presented in Table 2. Taking into account the results of the BCC model, which overcome the 
assumption that banks operate under condition of their optimal size, we can see that the leading position was reached by the Czech banking sector, whose average pure loan efficiency was $74.04 \%$ during the whole analysed period. The Slovak Republic ranked second (its average pure loan efficiency was $71.89 \%$ ). The banking sectors of Poland and Hungary ranked third and fourth most efficient, respectively. Czech banks reached the highest efficiency excluding years 2011 and 2013. In 2011 and 2013, the Slovak banking sector reached the highest score. Even if efficiency was monitored at the country level, we could follow the decline of efficiency since 2008, which peaked in 2011, and in 2013 in the Polish banking sector.

Table 2. Average pure loan efficiency in the V4 countries

\begin{tabular}{l|c|c|c|c}
\hline & Slovak Republic & Czech Republic & Hungary & Poland \\
\hline 2007 & $79.37 \%$ & $79.76 \%$ & $67.38 \%$ & $58.79 \%$ \\
\hline 2008 & $77.56 \%$ & $80.36 \%$ & $74.86 \%$ & $68.21 \%$ \\
\hline 2009 & $71.95 \%$ & $78.53 \%$ & $72.00 \%$ & $61.53 \%$ \\
\hline 2010 & $69.40 \%$ & $73.99 \%$ & $54.50 \%$ & $68.70 \%$ \\
\hline 2011 & $69.23 \%$ & $67.82 \%$ & $50.44 \%$ & $64.10 \%$ \\
\hline 2012 & $66.88 \%$ & $73.12 \%$ & $53.12 \%$ & $61.34 \%$ \\
\hline Average & $70.48 \%$ & $68.00 \%$ & $54.60 \%$ & $59.58 \%$ \\
\hline
\end{tabular}

Source: Author's calculations.

One of the important advantages of a DEA analysis is the ability to identify potential areas for the improvement of inefficient banks. The input-oriented model recommends inefficient units to achieve efficiency by reductions on the inputs side. The identification of the sources of inefficiency may help remove some barriers on the way to catch up with more efficient banks in the money lending business. In the entire analysed sample, we found that to improve efficiency it was necessary to reduce the value of bad loans and interest expenses by $34 \%$ on average. The highest reduction rate was required in 2011, when pure loan efficiency was at its lowest. For 2011, the reduction rate was $36.39 \%$ for NPLs and $38.06 \%$ for interest expenses. When we looked at the reduction rates separately according to the examined countries, we found that the highest reduction in the case of Slovak and Polish banks was required in 2012, while in the case of Czech and Hungarian banks, the highest reduction was required in 2011.

Another advantage of a DEA analysis is the ability to identify strengths and weaknesses within a set of inputs and outputs through the values of their optimal weights. On the one hand, lower weights signal factors which have a negative impact on efficiency. On the other hand, higher weights signal factors with a posi- 
tive impact on efficiency. When we looked at optimal weights obtained by solving the linear programming problems, we found that at the beginning of the analysed period, interest expenses was the weakest factor on the inputs side. Since 2010, the situation has changed, and NPLs took the role of the weakest factor. The analysis of strengths and weaknesses brought the same results on the national and international level.

In the final part of the analysis, we used the model of regression analysis (5) to examine how major structural characteristics of banks affected the efficiency of banks' lending behaviour. Major structural characteristics of banks were associated with assets, liabilities, profitability, earnings, liquidity, and capital structures of banks. Table 3 shows the selected explanatory variables, their descriptive statistics, and expected relationship with efficiency measured by pure loan efficiency (dependent variable).

Table 3. Banks' structural characteristics used in regression analysis

\begin{tabular}{l|r|r|r|c|c}
\hline Structural characteristics & $\begin{array}{c}\text { Maximum } \\
(\%)\end{array}$ & $\begin{array}{c}\text { Minimum } \\
(\%)\end{array}$ & \multicolumn{1}{c|}{$\begin{array}{c}\text { Average } \\
(\%)\end{array}$} & $\begin{array}{c}\text { Standard } \\
\text { deviation }\end{array}$ & $\begin{array}{c}\text { Expected } \\
\text { relationship }\end{array}$ \\
\hline Total Loans/Total Assets (TL/TA) & 86.85 & 19.77 & 61.53 & 14.7772 & - \\
\hline Total Loans/Total Deposits (TL/TD) & 305.53 & 25.69 & 107.26 & 47.6101 & + \\
\hline Liquid Assets/Total Assets (LA/TA) & 72.75 & 1.76 & 16.17 & 10.8968 & + \\
\hline Return on Average Assets (ROAA) & 4.25 & -23.26 & 0.54 & 2.3325 & + \\
\hline $\begin{array}{l}\text { Net Interest Income/(Net Interest + } \\
\text { Non-Interest Income) (NII/TI) }\end{array}$ & 154.67 & 36.39 & 74.97 & 11.1430 & + \\
\hline Capital/Risky Assets (CAR) & 43.77 & 3.71 & 13.44 & 3.6447 & $-/+$ \\
\hline $\begin{array}{l}\text { Non-Performing Loans/Total Loans } \\
\text { (NPL/TL) }\end{array}$ & 40.92 & 0.30 & 8.54 & 7.1697 & - \\
\hline
\end{tabular}

Source: Author's calculations.

The first explanatory variable was the indicator of commercial banks' assets structure expressed as total loans to total assets ratio (TL/TA). We assumed that a relatively high loan-to-asset ratio of a bank implies that the bank prefers lending to households or firms rather than investing in financial securities. That signals a higher liquidity risk, since the bank has more assets in the form of illiquid assets. We therefore assumed that banks with a higher loan-to-asset ratio (higher liquidity risk) have a lower efficiency. The existence of a negative relationship was described, for example, in the works of Hassan - Bashir (2003) and Rumler - Waschiczek (2012).

The second independent variable was the indicator of liabilities structure measured as a ratio of total loans to total deposits (TL/TD). The loan-to-deposit ratio depicts the credit creation by banks; therefore, we expected a positive sign. 
The third independent variable was the liquidity ratio, given as a share of liquid assets on total assets (LA/TA). A higher share of liquid assets indicates that the bank tends to be risk-averse in its lending and investing decisions. This indicator is an additional indicator of liquidity risk. If the value of liquid assets increases, the value of loans decreases. So we can say that if the TL/TA increases, the LA/ TA should decrease, therefore we expected a positive relation to efficiency.

The fourth independent variable was the indicator of banks' profitability measured by the ratio of return on average assets (ROAA). A higher share of profit indicates that the bank tends to have reached a higher profit per unit of average assets and has been more profitable in doing loan business, therefore we expected a positive relation to efficiency.

The fifth independent variable was the indicator of earning structure, which compared the net interest income to total net interest and non-interest incomes (NII/TI). This indicator signalises diversity in a bank's earning composition and we assumed that banks with higher efficiency had a higher share of net interest income than the least efficient banks.

The next independent variable was the indicator of capital structure measured as a ratio of capital and risky assets (CAR). Determination of a relationship in case of this variable is not entirely clear. One point of view is that capital adequacy ratio is expected to be positive, since it is assumed that banks will be rewarded additional revenues for holding the optimal amount of capital (e.g. Kosmidou et al. 2006). The other point of view is that capital adequacy ratio is expected to be negative (e.g. Tregenna 2009), since it is assumed that banks which have higher value of the capital cannot provide those funds in the form of loans and thereby reduce the value of the potential interest income which was used as an output in the DEA analysis.

The last explanatory variable was the share of NPLs on total loans (NPL/TL). Following Berger - DeYoung (1997), we expected a negative relation to pure loan efficiency, which confirms the so-called bad management hypothesis. According to that hypothesis, bad managers do not adequately control operating expenses and poorly manage the loan portfolio, which may lead to low efficiency and a large volume of problem loans.

The regression analysis was done separately for each country. The testing of the model was implemented in program R. The proposed model (5) was tested for statistical significance of the model (F-statistics). The normality of residues distributions was tested by the Jarque-Bera normality test. The presence of autocorrelation was tested by the Durbin-Watson test, the heteroskedasticity by the Breusch-Pagan test, and the multicollinearity by the VIF test. The correctness of the model's functional form was examined by the Ramsey's reset test. The detailed specification of the tests and the criteria for decision-making are described 
in the works of many authors (e.g. Želinský et al. 2010). The results of the regression are presented in Table 4. The results in Table 4 show that autocorrelation and heteroskedasticity were not detected in the models (the $p$-values in relevant tests are higher than the selected significance level).

The results in Table 4 show that for the Slovak Republic, the profitability (ROAA) had positive impact, while the quality of the loans portfolio (NPL/TL) had a negative impact on pure loan efficiency. Other variables were not marked as significant, and therefore we decided to exclude them systematically from the model according to the methodology proposed by Želinský et al. (2010). This should provide a better explanatory power to the model and more value to the

Table 4. Determinants of pure loan efficiency in V4 countries

\begin{tabular}{|c|c|c|c|c|}
\hline & Slovak Republic & Czech Republic & Hungary & Poland \\
\hline Intercept & $\begin{array}{r}0.89589^{* * *} \\
(13.403)\end{array}$ & $\begin{array}{r}1.00350 * * * \\
(11.572)\end{array}$ & $\begin{array}{r}-0.07075 \\
(-0.277)\end{array}$ & $\begin{array}{r}0.4922^{* * *} \\
(4.043)\end{array}$ \\
\hline TL/TA & --- & $\begin{array}{r}-1.59475^{* * *} \\
(-4.916)\end{array}$ & --- & --- \\
\hline TL/TD & --- & $\begin{array}{r}0.71772 * * * \\
(4.766)\end{array}$ & ---- & ---- \\
\hline $\mathrm{LA} / \mathrm{TA}$ & ---- & ---- & $\begin{array}{r}-0.98501 * \\
(-1.824)\end{array}$ & --- \\
\hline ROAA & $\begin{array}{r}5.09697 * * * \\
(3.386)\end{array}$ & $\begin{array}{r}7.48804 * * * \\
(3.916)\end{array}$ & --- & ---- \\
\hline $\mathrm{NII} / \mathrm{TI}$ & ---- & ---- & $\begin{array}{r}0.75129 * * \\
(2.250)\end{array}$ & ---- \\
\hline CAR & --- & ---- & $\begin{array}{r}3.80768 * * * \\
(5.167)\end{array}$ & $\begin{array}{r}1.5093^{* *} \\
(2.448)\end{array}$ \\
\hline NPL/TL & $\begin{array}{r}-3.42389 * * * \\
(-3.215)\end{array}$ & $\begin{array}{r}-0.71643 * \\
(-1.705)\end{array}$ & $\begin{array}{r}-1.91057 * * * \\
(-7.274)\end{array}$ & $\begin{array}{r}-2.0994 * * * \\
(-7.016)\end{array}$ \\
\hline ROAA $^{2}$ & - --- & $\begin{array}{r}44.99426 * * * \\
(2.973)\end{array}$ & --- & --- \\
\hline$(\mathrm{TL} / \mathrm{TA})^{2}$ & ---- & --- & ---- & $\begin{array}{r}0.2288^{* *} \\
(2.006)\end{array}$ \\
\hline No. of observations & 56 & 98 & 56 & 168 \\
\hline $\mathrm{R}^{2}$ & 0.3401 & 0.4783 & 0.7223 & 0.3931 \\
\hline F-statistics ( $p$-value) & $12.63(3.773 \mathrm{e}-05)$ & $12.1(2.474 \mathrm{e}-08)$ & $24.06(7.282 \mathrm{e}-10)$ & $23.11(1.313 \mathrm{e}-11)$ \\
\hline JB Test ( $p$-value) & $1.686(0.294)$ & $3.792(0.086)$ & $0.616(0.684)$ & $3.108(0.141)$ \\
\hline BP test ( $p$-value) & $0.3206(0.8519)$ & $1.9265(0.8592)$ & $5.0145(0.2858)$ & $4.1831(0.2424)$ \\
\hline DW test ( $p$-value) & $1.7528(0.1716)$ & $2.1877(0.7836)$ & $1.8964(0.3318)$ & $1.7909(0.1307)$ \\
\hline VIF test & No & No & No & No \\
\hline Reset test ( $p$-value) & $2.3219(0.07115)$ & $1.758(0.1351)$ & $2.3234(0,05)$ & $1.8902(0.1358)$ \\
\hline
\end{tabular}

Note: $* * * 0.01, * * 0.05, * 0.1 ; t$-value in parentheses in the independent variables.

Source: Author's calculations. 
Ramsey's reset test. When the profitability of the Slovak banks rose, the efficiency rose too. However, when the quality of the loan portfolio decreased (i.e. the share of NPLs on total loans increased), the efficiency decreased too. The results obtained from the regression analysis show that the coefficient of NPLs in the equation where pure loan efficiency is a dependent variable is negative and statistically significant, reaching $1 \%$. The results are consistent with the studies made by Berger - DeYoung (1997) and Karim et al. (2010), confirming that better management of credit risk led to lower value bad loans and this allowed banks to achieve higher efficiency. These findings are in line with the expectations expressed in Table 3.

For the Czech Republic, the original model was not correctly specified according to the value of the Ramsey's reset test. To resolve this problem, the original model was extended by the square of each variable. After having removed the insignificant variables, we found that the liabilities structure (TL/TD) and profitability (ROAA) had a positive impact on pure loan efficiency. Variables with a negative impact were the assets structure (TL/TA) and the share of non-performing loans on total loans (NPL/TL). These finding are in line with the expectations expressed in Table 3.

We obtained the highest value of the $\mathrm{R}^{2}$ for Hungarian banks. The original model was designed correctly, so it was only necessary to remove the insignificant variables. After removing the insignificant variables, we found that the earning structure (NII/TI) and the capital adequacy ratio (CAR) had a positive impact on pure loan efficiency. Variables with a negative impact were the share of liquid assets on total assets (LA/TA) and the share of non-performing loans on total loans (NPL/TL).

The last analysed country was Poland. In this banking sector, the original model was likewise not specified correctly according to the value of the Ramsey's reset test, so the extension by the square of each variable was necessary. After removing the insignificant variables, we found that the assets structure (TL/TA) and the capital adequacy (CAR) had a positive impact on pure loan efficiency. The variable with a negative impact was the share of non-performing loans on total loans (NPL/TL).

The negative impact of NPLs on total loans ratio on pure loan efficiency in each country confirmed the bad management hypothesis. According to the bad management hypothesis, managers did not adequately control operating expenses and poorly managed the loan portfolio, which led to low efficiency and large amount of problem loans. 


\section{CONCLUSION}

One of the consequences of the global financial crisis was the growth of NPLs and their share on total gross loans. Bad loans began to rise and the banking system faced the risk of a systemic failure. The increasing volume of NPLs affected financial institutions and the quality of the loan portfolio of banks.

The purpose of this paper was to evaluate the efficiency of the largest commercial banks in the V4 countries between 2007 and 2013 on a yearly basis, to focus on the banks' loan operations, and revenue generating behaviour.

Our results indicate that efficiency of the largest banks in the V4 countries has decreased since 2008. Individually, each country exhibited approximately the same trend. The increasing inefficiency of the banking sectors can be predominantly attributed to increasing credit losses, which confirmed an increase of the average share of bad loans from 5\% in 2007 to a failure rate of over 10\% in 2013. Taking into account the results of the BCC model, which overcame the assumption that banks operated in conditions of their optimal size, we can see that the best performance was displayed by the Czech banking sector, where the average pure loan efficiency was $74.04 \%$ during the whole analysed period. The banking sector in the Slovak Republic ranked $2^{\text {nd }}(71.89 \%)$, in Poland and Hungary ranked $3^{\text {rd }}$ and $4^{\text {th }}$, respectively. Czech banks reached the highest efficiency excluding the years 2011 and 2013. In 2011 and 2013, the Slovak banking sector reached the highest score.

In addition, this study highlighted the links between the structural characteristics of commercial banks and efficiency. Regarding the Slovak Republic, this analysis mainly implies that profitability had a positive impact and the quality of the loans portfolio had a negative impact on pure loan efficiency. As for Czech banks, the liabilities structure and profitability had a positive impact on pure loan efficiency, while the assets structure and the share of NPLs on total loans were variables with a negative impact. The efficiency of Hungarian banks was positively related to the earning structure and the capital adequacy ratio and negatively related to the share of liquid assets on total assets and the share of bad loans on total loans. As regards Polish banks, the assets structure and capital adequacy had a positive impact on pure loan efficiency and the share of non-performing loans on total loans was the variable with a negative impact. The negative impact of bad loans on total loans ratio on pure loan efficiency in each country confirmed the bad management hypothesis, according to which managers did not adequately control operating expenses and poorly managed the loan portfolio, which resulted in low efficiency and a large volume of problem loans.

The potential contributions of this paper to the recent publications are the following: firstly, with regard to the recent development in the V4 banking sec- 
tors, this study focuses on the loan activities and profit generation behaviour of banks in the efficiency analyses. The study constitutes a new approach to the V4 banking efficiency measurement, evaluating only the loan business of the largest banks in the V4 countries. Secondly, the results of the regression analysis imply that the most efficient banks in the V4 countries (except for Hungary) over the analysed period are aggressive in their loan business, as proved by the increasing average values of total loans/total assets and total loans/total deposits, and by the decreasing average of liquid assets/total assets between 2007 and 2013. The average value of total loans/total assets in the Slovak banks (designated as efficient) increased from $49.82 \%$ in 2007 to $63.82 \%$ in 2013 . The average value of total loans/total deposits increased from $71.37 \%$ to $94.87 \%$ and the average value of liquid assets/total assets decreased from $22.57 \%$ to $9.44 \%$. The same trend can be observed in the Czech (TL/TA: $38.31 \%-51.16 \%$; TL/TD: $72.07 \%-75.35 \%$; LA/TA: $60.62 \%-14.59 \%$ ) and Polish efficient banks (TL/TA: $51.78 \%-64.99 \%$; TL/TD: $65.25 \%-89.06 \%$; LA/TA: $31.27 \%-13.09 \%$ ). The indicated trend is supported also by the sample of efficient and non-efficient banks. As for efficient banks such as VUB, a.s. (Slovak Republic), Česká sporitel'ňa, a.s. (Czech Republic) and ING Bank Śląski S.A. (Poland), the value of total loans/total assets increased from $45.69 \%$ to $65.54 \%, 44.31 \%$ to $51.16 \%$, and from $31.49 \%$ to $55.97 \%$, respectively. The increase was recorded in the ratio of total loans/total deposits, i.e. an increase from $65.26 \%$ to $100.96 \%, 61.23 \%$ to $75.35 \%$, and from $39.44 \%$ to $75.55 \%$. As for inefficient banks such as Poštová Banka, a.s. (Slovak Republic), J\&T Banka, a.s. (Czech Republic), CIB Bank Zrt. (Hungary), and Bank Gospodarstwa Krajowego (Poland), the value of ratios decreased (TL/TA: $59.13 \%-50.45 \%$; 74.48\%-46.55\%; 79.23\%-67.73\%; 39.70\%-24.40\%; TL/TD: $104.42 \%-63.01 \%$; 94.60\%-65.63\%; 156.80\%-138.18\%; 72.97\%-38.05\%).

The findings reported in this paper should be updated in a wider context, for example in the EU area (in order to examine the development of the V4 countries' efficiency in a wider array of surveyed countries). Moreover, repeating the efficiency analysis from the output-oriented point of view would allow for the determination of the minimum acceptable interest revenues for the given interest expenses and value of NPLs required to reach efficiency. The benefits of a future analysis may include also a parametric method such as SFA, which uses information about prices to evaluate cost, revenue, or profit efficiency. 


\section{REFERENCES}

Akkoc, S. - Vatansever, K. (2013): Fuzzy Performance Evaluation with AHP and Topsis Mehtods: Evidence from Turkish Banking Sector after the Global Financial Crisis. Eurasian Journal of Business and Economics, 6(11): 53-74.

Barr, R. - Siems, T. (1994): Predicting Bank Failure using DEA to Quantify Management Quality. Federal Reserve Bank of Dallas, Financial industry Studies, Working papers, No. 94.

Berger, A.N. - DeYoung, R. (1997): Problem Loans and Cost Efficiency of Commercial Banks. Journal of Banking and Finance, 21(6): 849-870.

Berger, A.N. - Humphrey, D.B. (1992): Measurement and Efficiency Issues in Commercial Banking. In: Griliches, Z. (eds): Output Measurement in the Service Sector. University of Chicago Press, pp. 245-300.

Charnes, A. - Cooper, W. - Rhodes, E. (1978): Measuring the Efficiency of Decision-Making Units. European Journal of Operational Research, 2(6): 429-444.

Cinar, Y. (2011): Efficiency Dynamics and Structural Characteristics of the Largest Commercial Banks in Turkey. Экономический журнал Высшей школь экономики, 15(3): 315-335.

Dai, G. (2010): Research on Loans Efficiency of Commercial Bank Based on DEA. Paper presented at the 2010 International Conference on Management and Service Science (MASS), August $24-26$, Wuhan, China.

Demirgüç-Kunt, A. (1989): Deposit-Institution Failures: A Review of Empirical Literature. Federal Reserve Bank of Cleveland, Economic Review, (4): 2-18.

DeYoung, R. - Whalen, G. (1994): Is a Consolidated Banking Industry a More Efficient Banking Industry? Quarterly Journal, 13(3): 11.

Funso, K.T. - Kolade, A.R. - Ojo, O.M. (2012): Credit Risk and Commercial Banks' Performance in Nigeria: A Panel Model Approach. Australian Journal of Business and Management Research, 2(2): 31-38.

Gavurová, B. (2011): The Balanced Scorecard System in Enterprise Management. Ekonomický časopis, 59(2): 163-177.

Gavurová, B. (2012): Source Identification of Potential Malfunction of Balanced Scorecard System and Its Influence on System Function. E+M Ekonomie a management, 15(3): 76-90.

Hartman, T.E. - Storbeck, J.E. (1996): Input Congestion in Loan Operations. International Journal of Production Economics, 46-47: 413-421.

Hassan, M.K. - Bashir, A.M. (2003): Determinants of Islamic Banking Profitability. Paper presented at 10th ERF Annual Conference, Morocco.

Hughes, J.P. - Moon, Ch.G. (1995): Measuring Bank Efficiency When Managers Trade Return for Reduced Risk. Rutgers University, Department of Economics, Working Papers, No. 20.

Karim, M.Z.A - Chan, S.G. - Hassan, S. (2010): Bank Efficiency and Non-Performing Loans: Evidence from Malaysia and Singapore. Prague Economic Papers, 19(2): 118-132.

Kočišová, K. (2013): An Analysis of Bank Efficiency in the Slovak and the Czech Republic by Data Envelopment Analysis. Paper presented at the International Conference QUAERE 2013, May 20-24, Hradec Králové, Czech Republic. Available at: <http://www.vedeckekonference.cz/library/proceedings/quaere_2013.pdf.>

Kosmidou, K. - Pasiouras, F. - Doumpos, M. - Zopounidis, C. (2006): Assessing Performance Factors in the UK Banking Sector: A Multicriteria Methodology. Central European Journal of Operations Research, 14(1): 25-44.

Kwan, S. - Eisenbeis, R. (1996): An Analysis of Inefficiencies in Banking: A Stochastic Cost Frontier Approach. Economic Review, 2: 16-26. 
Resti, A. (1996): Linear Programming and Econometric Methods for Bank Efficiency Evaluation: An Empirical Comparison Based on a Panel of Italian Banks. In: Bertocchi, M. - Cavalli, E. - Komlosi, S. (eds): Modelling Techniques for Financial Markets and Bank Management. Heidelberg: Physica-Verlag, pp. 111-139.

Rossi, S.P.S. - Schwaiger, M. - Winkler, G. (2005): Managerial Behavior and Cost/Profit Efficiency in the Banking Sector of Central and Eastern European Countries. Austrian Central Bank, Working Paper, No. 96.

Rumler, F. - Waschiczek, W. (2012): Have Changes in the Financial Structure Affected Bank Profitability? Evidence for Austria. Oesterreichische Nationalbank, Working Paper, No. 180

Scheel, H. (2000): EMS: Efficiency Measurement System, User's Manual. Version 1.3. Dortmund. Available at: < http://www.scheel-online.de/ems/ems.pdf >

Shaverdi, M. - Akbari, M. - Tafti, S.F. (2011): Combining Fuzzy MCDM with BSC Approach in Performance Evaluation of Iranian Private Banking Sector. Advances in Fuzzy Systems, 1: $1-12$.

Sherman, D. - Gold, F. (1985): Branch Operating Efficiency: Evaluation with Data Envelopment Analysis. Journal of Banking and Finance, 9(9): 297-315.

Stavárek, D. (2003): European Banking Efficiency: A Cross-Country Analysis of Transition and Developed Banking Sectors. Fifth International Conference Aidea Giovani: Information, Markets and Firms, July 3-4, 2003, Milano, Italy.

Šoltés, V. - Gavurová, B. (2013): Application of the Cross Impact Matrix Method in Problematic Phases of the Balanced Scorecard System in Private and Public Sector. Journal of Applied Economic Sciences, 8(1): 99-119.

Tabak, B.M. - Cajueiro, D.O. - Craveiros, G.L. (2011): Bank Efficiency and Non-Performing Loans in Brazil: Causality Tests. FGV Conferences, 33th Meeting of the Brazilian Econometric Society, December 7-9, 2011, Brasil.

Tregenna, F. (2009): The Fat Years: The Structure and Profitability of the US Banking Sector in the Pre-Crisis Period. Cambridge Journal of Economics, 33(4): 609-632.

Wheelock, D.C. - Wilson, P.W. (1995): Explaining Bank Failures: Deposit Insurance, Regulation, and Efficiency. Review of Economics and Statistics, 77(4): 689-700.

Williams, J. (2004): Determining Management Behaviour in European Banking. Journal of Banking and Finance, 28(10): 2427-2460.

Zago, A. - Dongili, P. (2006): Bad Loans and Efficiency in Italian Banks. Universita Degli Studi di Verona, Dipartimento di Scienze Economiche, Working Paper Series, No. 28.

Zijang, Y. (2006): A Two-Stage DEA Model to Evaluate the Overall Performance of Canadian Life and Health Insurance Companies. Mathematical and Computer Modelling, 43(7-8): 910-919.

Želinský, T. - Gazda, V. - Výrost, T. (2010): Ekonometria. Košice: Technical University. 